\title{
Structural Equation Modeling Based on Variance Density Index of Larvae of the Rainy Season in the City of Banjarbaru
}

\author{
Isnawati1,3, Bambang Widjanarko Otok ${ }^{2}$, Suharto ${ }^{3}$, Arief Wibowo ${ }^{3}$ \\ ${ }^{1}$ Health Polytechnic Banjarmasin, Ministry of Health \& Ph.D Student Faculty of Public \\ Health, Airlanga University, Surabaya \\ ${ }^{2}$ Laboratory of Environmental and Health Statistic, Institut Teknologi Sepuluh \\ Nopember, Surabaya, INDONESIA \\ ${ }^{3}$ Department of Biostatistics and Demography, Faculty of Public Health, Airlanga \\ University, Surabaya,
}

Email: 1isna.husaini1@gmail.com , 22dr.otok.bw@gmail.com

\begin{abstract}
Climate change causes changes rainfall, temperature, air humidity and wind direction so that affect the reproduction of vectors of diseases such as the mosquito Aedes, Malaria, etc. that it needs to be monitored the increase in many cases DB. free number of larvae (ABJ) is one of the larva density indicator, although $\mathrm{ABJ}$ has more than 90 percent but morbidity remains high. The condition of the $\mathrm{ABJ}$ not describes the density of larvae jentik, so that the need to study the density jentik indicator that more can describe as the larvae density index with SEM based Variance approach. The results of the study showed that the structural model nonparametric to larva density is the best model based on the criteria of $\mathrm{R}^{2}$ and $\mathrm{Q}^{2}$. The Ministry of Health and behavior, environment condition and breeding place/site effect on the larva density of $87.7 \%$. The dominant indicator counseling on health services, knowledge on the behavior of the temperature of the water on the conditions in the environment and the material container on the breeding place/sites. While on the larva density each indicator provides value loading, larvae density index (0.864), House index (0.459), Container index (0.894), and Breateau index (0.925). Environmental conditions the dominant factor in affecting larva density decline of $32.4 \%$, with each indicator larvae density index (28\%), House index (15\%), Container index (29\%), and Breateau index (30\%).
\end{abstract}

Keywords: SEM based Variance, larva density, $\mathrm{R}^{2}, \mathrm{Q}^{2}$

\section{INTRODUCTION}

Causes of extraordinary events (KLB) is a condition of the emergence or increased incidents of pain or death by epidemiologis on a region in a specific period of time. In 2013, patients with dengue fever which spread all over the country by 112511 cases, while in the year 2014, cases dengue fever decline of 100347 cases with death as much as 907 people [1].

In Indonesia dengue fever is still the main health problems and until this time was interested in medicine and not yet available when this disease can be transmitted quickly by the mosquito Aedes aegypti so that potential to cause a pandemic [2]. The end of the year 2014 was recorded as much as 433 from 508 regency/city (85.2\%) has been infected with dengue fever with the total number of cases 100347 (Morbidity: 39.83 per 100000 inhabitants) with 907 cases died (Death Rate: 0.90\%), and in 2015 recorded 9 provinces that have increased cases of dengue fever and there are 2 provinces that have 
morbidity (Inciden Rate/IR) Dengue Fever above national targets 49 per 100000 inhabitants, South Kalimantan and East Kalimantan [1].

The case of dengue fever in South Kalimantan in the last three years there has been increased with IR 2013 (31.31 per 100000 inhabitants), the year 2014 (21.53 per 100000 inhabitants), and there is an increase in the 2015 namely 70.17 per 100000 inhabitants of 49 per 100000 population [3]. From 13 regencies/cities in South Kalimantan Banjarbaru City in the last three years also has increased, even 2015 IR jumped sharply until 230,73 per 100000 inhabitants of IR in the previous year 89.48 per 100000 inhabitants and on the years down to the numbers 11.45 per 100000 population [3].

Various intervention done for pressing the case of dengue fever is still high as fogging, eradication of the nest lice (PSN) or 3M Plus, but ABJ until 2015 still fluctuate from 2013 of $68.02 \%$ and prevent larva behavior according to [4], 77.4 percent new is still below the target. The year 2014 and 2015 ABJ of $93.46 \%$ [3]. Up to this moment this disease can only be controlled with termination chain of transmission vektornya because drugs and vaccines of this disease is still not yet [5] and a research in Australia shows that stop the supervision of mosquitoes can improve epidemic management costs compared with the strategy sustainable surveillance and early detection of cases [6]. One of them is the supervision of the larvae.

In the case of dengue fever there is some latent variables such as environmental conditions, vectors and remain indifferent. one of analysis techniques that are often used to describe the relationship or the influence of the complex between the variable is the modeling technique statistics Structural Equation Modellng (SEM) who have the ability to analyze the pattern of the relationship between the latent konstrak and the indicators, or the latent konstrak with each other, and measurement error directly. SEM allows analysis done among some endogenous dependent variables and independent exogenous supply directly [7]. Many counting provides data analysis model biased on parametrik method. Data analysis approach is also directed as nonparametrik technique and if the available information about the regression curve is limited and difficult to make the assumptions of regression form, then the largest part of the information located on the data pattern, so to suspect the regression curve can be used non parametrik regression that analytical is not based on a specific spread [8].

The diversity of data and there is a parameter or indicators that form the latent variable of the conditions in the analysis of the structural model and some variables which contribute in Genesis a disease can be formed from various types of data. Nominal, ordinal, interval or ratio data and conditions if that is more flexible to be analyzed with SEM Nonparametric, including a small number of sample, The existence of lost data (missing values), and multicolinierity. According to [7] perform the estimation of model parameters Partial Least Square (PLS) on poverty issues, and [9] shows that in the decision-making in the field of health SEM PLS more perspective and realistic for empirical analysis. According to [10] using nonparametric model structure only to estimation income and environmental emissions, while [11], and [12] trying to find a suitables parameters in a model of SEM is used as a basis for inference and prediction.

With the increasing case of dengue fever, it needs to be examined larva density model with the approach of nonparametric SEM, so that by knowing the factors that affect the density of larva decline expected can be used as a reference for the prevention and control of a case of dengue fever. 


\section{METHODS}

The research population is all housewife in twelve kelurahan endemic with 296 household in the city Banjarbaru on 2016 and sample research is a housewife who was selected in the determination of the sample size based on the cluster method rapid survey [13]. The size of the samples used in this research is the cluster 30 household in twelve kelurahan endemic in the working area of the clinic and each cluster with 7 samples so that the number of the whole sample is 210 house wife who is location in the City of Banjarbaru.

The variables examined consists of the endogenous latent variables and exogenous supply along with the variables the indicators. The latent variables were five laten, namely latent variable larva density with four indicator variables Larva Density Index, House Index, Container Index, and Breateu Index. Behavior consists of three indicator variables, namely knowledge, attitudes and actions. The latent variable breeding places/site in this case is container consists of indicator variable, material, type, cover, and the color of the container. The latent variable environmental conditions consist of four indicator variables are the source of water, water temperature and $\mathrm{pH}$ of the water in the container and the latent variable health services consists of four indicator variables, namely larvasidasi, fogging, periodic larva examination, and conselling service. The conceptual research presented as follows.

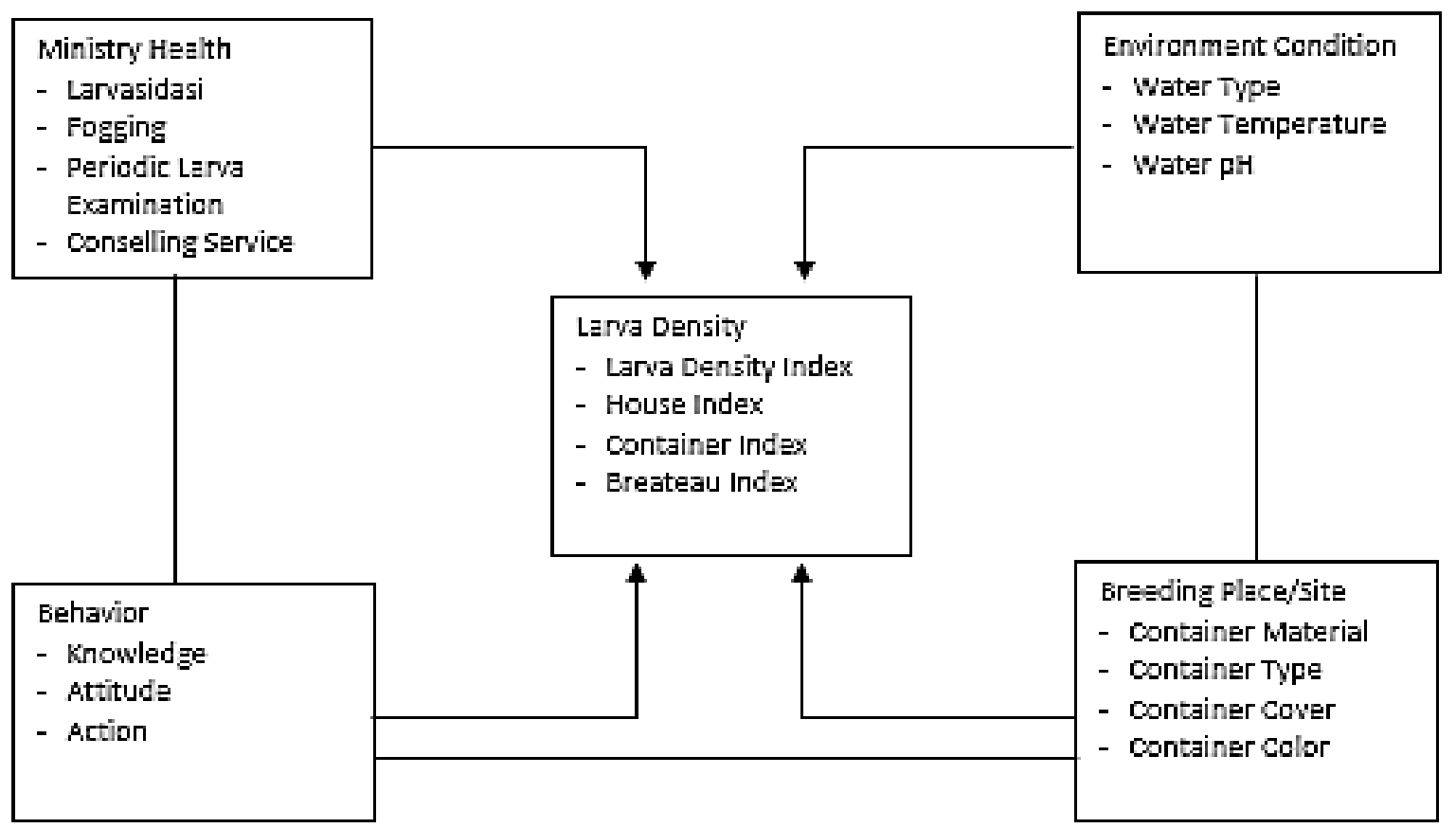

Figure 1. The framework of the concept of larva density prediction Aedes sp in the City Banjarbaru [14]

The Data in this research using the primary data and then done analysis with the modeling of SEM PLS. The modeling of SEM that is done by using Partial Least Square (PLS) with the steps as follows [15]:

1. Outer Model, covers the validity test is seen from the results of loading factor, and reliability tests seen from the value of Composite reliability. The indicator is called 
valid if has a value of loading factor $>0.5$ and said reliable if the value of composite reliability $>0.6$.

2. Inner Model, test this can be seen as a result of the value of the inner weight to test the formulation of research hypothesis through $t$ test on the bootstrap samples and goodness of fit model. The model can be stated to have the goodness of fit if has a value R-Square $>0$ and the value of $\mathrm{Q}^{2}>0.35$ provides high accuracy.

\section{RESULTS AND DISCUSSION}

Description of this research includes the mean and standard deviation from each indicator on the research variables. Now in detail is presented in the following table.

Table 1. Descriptive Statistic of Research Variables

\begin{tabular}{|c|c|c|}
\hline No & The characteristic & Percentage (\%) \\
\hline \multicolumn{3}{|c|}{ Ministry of Health } \\
\hline \multirow[t]{4}{*}{1.} & Larvasidasi : & \\
\hline & Less $(<60 \%)$ & 72.4 \\
\hline & Just (60\%-75\%) & 8.1 \\
\hline & Good (>75\%) & 19.5 \\
\hline \multirow[t]{4}{*}{2.} & Fogging & \\
\hline & Less $(<60 \%)$ & 77,6 \\
\hline & Just (60\%-75\%) & 9.0 \\
\hline & Good (>75\%) & 13.3 \\
\hline \multirow[t]{4}{*}{3.} & Periodic Larva examination (PJB) & \\
\hline & Less $(<60 \%)$ & 84,8 \\
\hline & Just (60\%-75\%) & 2.9 \\
\hline & Good $(>75 \%)$ & 12.4 \\
\hline \multirow[t]{4}{*}{4.} & Counseling Services & \\
\hline & Less $(<60 \%)$ & 81,9 \\
\hline & Just (60\%-75\%) & 4.3 \\
\hline & Good (>75\%) & 13.8 \\
\hline \multicolumn{3}{|c|}{ Behavior } \\
\hline \multirow[t]{4}{*}{1.} & Knowledge : & \\
\hline & Less & 20.8 \\
\hline & Enough & 51.9 \\
\hline & Good & 26.4 \\
\hline \multirow[t]{3}{*}{2.} & Attitude: & \\
\hline & Less & 4.8 \\
\hline & Good & 95.2 \\
\hline \multirow[t]{4}{*}{3.} & Action: & \\
\hline & Less & 50.5 \\
\hline & Enough & 29.5 \\
\hline & Good & 20.0 \\
\hline
\end{tabular}


Table 2. Descriptive Statistic of Research Variables (Continues)

\begin{tabular}{|c|c|c|}
\hline No & The characteristic & Percentage $(\%)$ \\
\hline \multicolumn{3}{|c|}{ Environment Condition } \\
\hline \multirow[t]{3}{*}{1.} & Type of water/clean water sources : & \\
\hline & Non Piping dug wells, boreholes others) & 61.4 \\
\hline & Pipelines $(P D A M)$ & 38.6 \\
\hline \multirow[t]{3}{*}{2.} & The water temperature: & \\
\hline & Support the growth $\left(25^{\circ} \mathrm{C}-27^{\circ} \mathrm{C}\right)$ & 45.7 \\
\hline & Less support growth $\left(<25^{\circ} \mathrm{C}\right.$ and $\left.>27^{\circ} \mathrm{C}\right)$ & 54.3 \\
\hline \multirow[t]{3}{*}{3.} & Water $\mathrm{pH}:$ & \\
\hline & Support the growth (pH 5.8-8.6) & 0 \\
\hline & Less support growth $(\mathrm{pH}<5.8$ or $\mathrm{pH}>8.6)$ & 100 \\
\hline \multicolumn{3}{|c|}{ Breeding Place/site } \\
\hline \multirow[t]{4}{*}{1.} & Container material: & \\
\hline & The metal contacts/metal & 5.7 \\
\hline & Cement & 31.0 \\
\hline & Plastic & 63.3 \\
\hline \multirow[t]{4}{*}{2.} & Container Type: & \\
\hline & Water Reservoirs (TPA) & 71.36 \\
\hline & Non-Water Reservoirs (non TPA) & 27.17 \\
\hline & Experience & 1.45 \\
\hline \multirow[t]{3}{*}{3.} & Container Cover: & \\
\hline & There is no cover & 60,0 \\
\hline & There is the cover & 40 \\
\hline \multirow[t]{3}{*}{4.} & Container Color: & \\
\hline & Dark (black, gray) & 21.4 \\
\hline & The light (red, pink Blue, Green, white orange) & 78.6 \\
\hline \multicolumn{3}{|c|}{ Larva density } \\
\hline 1 & Larva Density Index/LDI & 18.21 \\
\hline 2 & House Index /HI (\%) & 37.62 \\
\hline 3 & Container Index/CI (\%) & 14.32 \\
\hline 4 & Breuteu Index /BI (\%) & 55.71 \\
\hline 5 & Numbers free jentik/ABJ (\%) & 62.38 \\
\hline 6 & Density figure /DF & 5.67 \\
\hline
\end{tabular}

Table 2 shows that most of the mother of households with health services from the health officer at 5.2 percent to 19.5 percent stated that the ministry of health by the officers in the prevention of vector diseases Dengue Fever is good. More Intensive health services done in the rainy season so that health officials in the ministry of health to become more active. The behavior of the mother of the household in which related with knowledge, attitudes, customs and pencegahannnya efforts against vector Dengue Fever by 51.9 percent is good. Environmental conditions in this research is related to water reservoirs (TPA) as a place to live jentik mosquitoes Aedes aegypti, most of the sources of water used population is not water piping water dug wells, boreholes, river) namely ranges 61.4 percent. Physical condition of water a qualify namely odourless, no color, odorless.

The temperature of the water in the containers ranging between $25^{\circ} \mathrm{C}-31^{\circ} \mathrm{C}$, according to the ministry [16] in general temperature to the place of the multiplication of mosquitoes aedes ranged between the temperature of $25^{\circ} \mathrm{C}-27^{\circ} \mathrm{C}$. The development of optimally for living water at a temperature $25^{\circ} \mathrm{C}$ until $27^{\circ} \mathrm{C}$ larvae will die at a temperature less than $10^{\circ} \mathrm{C}$ or more than $40^{\circ} \mathrm{C}$. Water temperature can also be 
influenced by air temperature, normally, water temperature ranged between $\pm 3^{\circ} \mathrm{C}$ with air temperature [17].

Water $\mathrm{pH}$ rainy season conditions support, ranging from 4-8 $\mathrm{pH}$ level of water affects the level of $\mathrm{O}_{2}$ and $\mathrm{CO}$, while $\mathrm{O}_{2}$ will be deposited. $\mathrm{pH}$ is normal for the development of mosquitoes from laying eggs to become pupae ranged between 4 - 9 , and $\mathrm{PH}$ of the water in the container is good for the reproduction of larva Aedes aegypty ranged between 5.8 - 8.6 [18]. Massive pH range from 0 (very acid) to 14 (very base/alkalis). The value of $\mathrm{pH}$ less than 7 shows an environment of acid while the value above 7 indicates the base environment (alkaline). While $\mathrm{pH}=7$ is called as neutral [19]. The level of $\mathrm{O}_{2}$ and $\mathrm{CO}$ in the water also affect the formation of the enzyme oxidation sinokrom Aedes aegypti larvae sp. and Aedes albopictus sp. The fluctuations in $\mathrm{pH}$ water is in specify by alkalinity water.

The manner vector diseases Dengue Fever or jentik larvae mosquitoes Aedes, sp called breeding place/site. At the place that is observed is container, good ingredients, type, there is whether or not the cover, and the color of the container. The container with the rainy season more dominant namely 63.3 percent, the ingredients are the most used by the housewife is a plastic 39.11 percent. Close the container that is used is also there that can be filled with water so that allows for a place larva to multiply.

The color of the container that used household most or more than 70 percent bright as red, blue, green. Larva density can be seen from some of the size of such as House Index (HI), Container Index (CI), Breuteu Index (BI), Density figure (DF), and Larval Density Index (LDI). In the rainy season jentik density of each house is relatively homogeneous namely range between the lowest infection rate was from 0.00 to 58,14 jentik or the average range 18.21 around 18-19 jentik each house. The type of jentik or the larvae found on the containers in household on rainy season is 77.8 percent larva Aedes aegypty and 22.2 percent Aedes Albopictus.

Index larva a House Index (HI) is also able to show the size for free number larva (ABJ), namely if the rainy season with $\mathrm{HI}$ between $23.81-67.86$ percent with the average 37.62 percent means numbers free larva is 62,38 percent. Breuteu Index (BI) the existence of larva seen each 100 houses, the rain around 56 houses which have a positive container. The rainy season DF (5.33), including regions are being or need to be cautious in the transmission of the disease by the larvae, and epidemiology DF $>1$ including risk in the transmission of dengue fever [1], [20], [21].

Data analysis the research using SEM by involving the validity test and reliability using through Confirmatory Factor Analysis (CFA) and Contruct Reliability using the program SmartPLS. Validity test is intended to determine whether the questions in the questionnaire just representative. Validity test is done by using confirmatory factor analysis on each of the latent variable. The second measure test is reliable, namely the index shows the extent to which reliable measure or can be trusted. Reliability is the size of the internal consistency of the indicators a variables proxies which shows the degree to which each indicator it indicates a variable common adjectives more detailed results are presented in Table 3. 
Table 3. Validity and Reliability Convergence of the Indications on Laten Variables

\begin{tabular}{|c|c|c|c|c|c|c|}
\hline \multirow[b]{2}{*}{ The variables } & \multirow[b]{2}{*}{ The indicator } & \multicolumn{3}{|c|}{ Validity Convergence } & \multirow{2}{*}{$\begin{array}{c}\text { Validity } \\
\text { Discriminant }\end{array}$} & \multirow{2}{*}{$\begin{array}{l}\text { Composite } \\
\text { Reliability }\end{array}$} \\
\hline & & $\begin{array}{l}\text { Loading } \\
\text { Factor }\end{array}$ & P-value & Conclusion & & \\
\hline \multirow{4}{*}{$\begin{array}{l}\text { Ministry of } \\
\text { Health }(\mathrm{X})\end{array}$} & Larvasidasi (X1) & 0.691 & 0.686 & 8.185 & \multirow{4}{*}{0.695} & \multirow{4}{*}{0.799} \\
\hline & Fogging (X2) & 0.714 & 0.715 & 6.646 & & \\
\hline & PJB (X3) & 0.601 & 0.575 & 5.003 & & \\
\hline & $\begin{array}{l}\text { Counseling Service } \\
\text { (X4) }\end{array}$ & 0.795 & 0.772 & 9.052 & & \\
\hline \multirow[t]{3}{*}{ Behavior (Y1) } & Knowledge (Y1.1) & 0.716 & 0.723 & 6.360 & \multirow{3}{*}{0.643} & \multirow{3}{*}{0.669} \\
\hline & Attitude (Y1.2) & 0.708 & 0.678 & 6.766 & & \\
\hline & Action (Y1.3) & 0.562 & 0.543 & 5.522 & & \\
\hline \multirow{3}{*}{$\begin{array}{l}\text { Environment } \\
\text { condition } \\
\text { (Y2) }\end{array}$} & Type of water (Y2.1) & 0.649 & 0.647 & 9.832 & \multirow{3}{*}{0.603} & \multirow{3}{*}{0.670} \\
\hline & $\begin{array}{l}\text { The water } \\
\text { temperature (Y2.2) }\end{array}$ & 0.665 & 0.657 & 10.539 & & \\
\hline & PH water (Y2.3) & 0.588 & 0.590 & 8.075 & & \\
\hline \multirow{4}{*}{$\begin{array}{l}\text { Breeding } \\
\text { Place/site } \\
\text { (Y3) }\end{array}$} & $\begin{array}{l}\text { Container materials } \\
\text { (Y3.1) }\end{array}$ & 0.963 & 0.962 & 124.888 & \multirow{4}{*}{0.898} & \multirow{4}{*}{0.708} \\
\hline & $\begin{array}{l}\text { The type of containers } \\
\text { (Y3.2) }\end{array}$ & 0.950 & 0.950 & 116.528 & & \\
\hline & $\begin{array}{l}\text { The container cover } \\
\text { (Y3.3) }\end{array}$ & 0.920 & 0.919 & 64.784 & & \\
\hline & $\begin{array}{l}\text { The color of the } \\
\text { container (Y3.4) }\end{array}$ & 0.957 & 0.956 & 169.037 & & \\
\hline \multirow[t]{4}{*}{$\begin{array}{l}\text { Larva density } \\
\text { (Y4) }\end{array}$} & $\begin{array}{l}\text { Larva density index } \\
\text { (Y4.1) }\end{array}$ & 0.864 & 0.864 & 56.534 & \multirow{4}{*}{0.652} & \multirow{4}{*}{0.973} \\
\hline & House index (Y4.2) & 0.459 & 0.454 & 11.051 & & \\
\hline & Container index (Y4.3) & 0.894 & 0.895 & 57.346 & & \\
\hline & Breateau index (Y4.4) & 0.925 & 0.922 & 67.551 & & \\
\hline
\end{tabular}

After the validity and reliability test on all latent variables which valid results and reliabel, then done test the suitability of the structural model on the Larva density. The full Model Larva Density chart form as follows. 


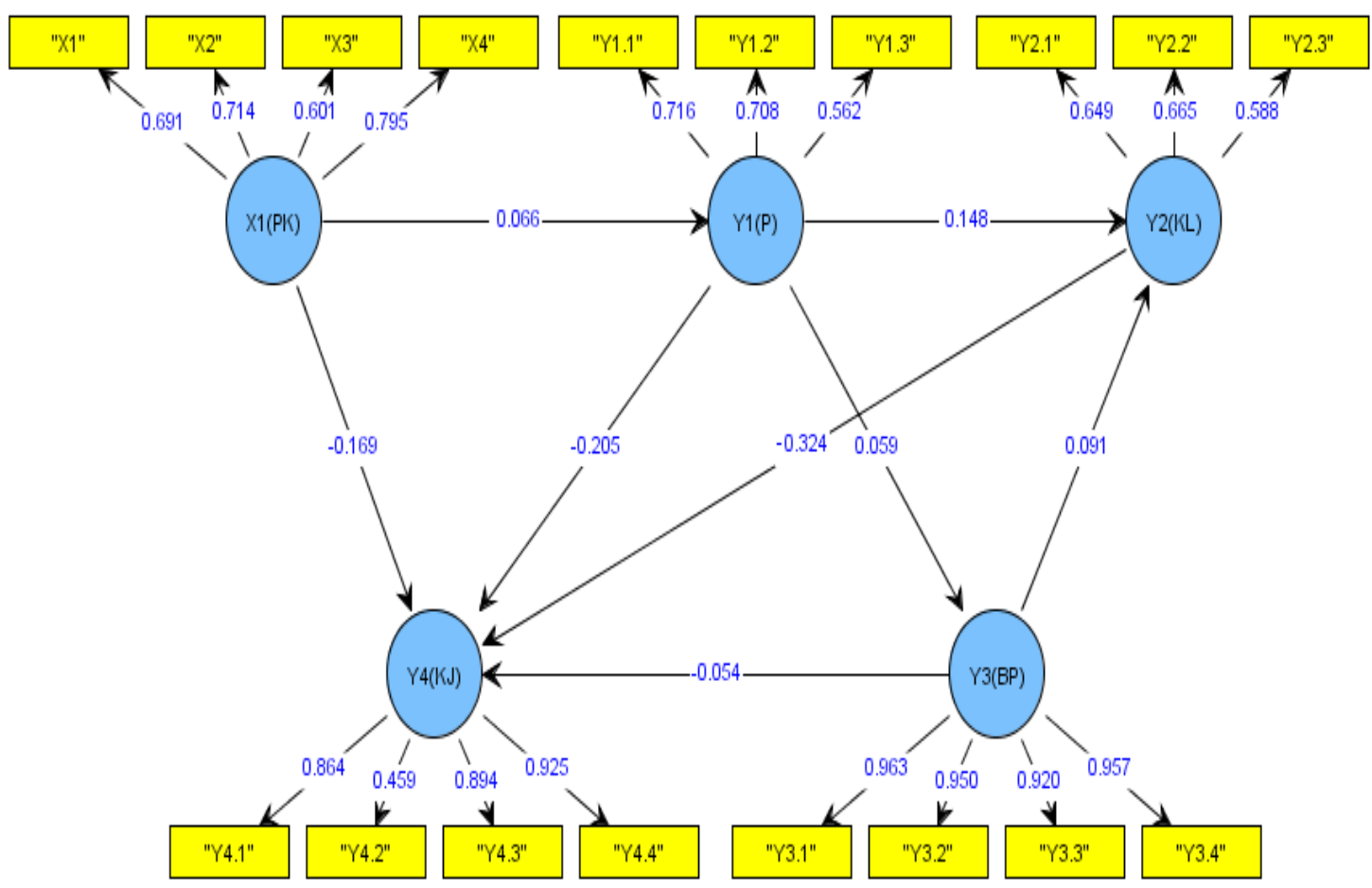

Figure 2. The Relationship of Ministry Health, Behavior, Environment Condition, Braiding Place against the Larva density on Rainy Season

The results of the complete model testing in SmartPLS program can be seen from the values R-Square that illustrates the goodness of the fit of a model. The value of RSquare that is recommended is greater than zero. The results of this research data processing using SmartPLS provides value R-square as is shown in Table 3.

Table 4. Goodness of Fit Model Larva density on Rainy Season

The variables

Ministry Health (X1) $\rightarrow$ Behavior (Y1)

0.204

Behavior (Y1), Breeding Place/Site (Y3) $\rightarrow$ Environment Condition (Y2)

0.229

Environment condition (Y2) $\rightarrow$ Breeding Place/Site (Y3)

Ministry Health (X1), Behavior (Y1), Environment Condition (Y2), Breeding Place/Site (Y3) $\rightarrow$ Larva density (Y4)

Table 4 explains that:

- Contributions or the proportion of ministry health (X1) variables in explaining the variations around the behavior (Y1) of variables of gaining of 0.204.

- Contributions or the proportion of behavior variables (Y1), Breeding Place/ Site (Y3) in explaining the variation around environmental conditions variable (Y2) of 0.229.

- Contributions or the proportion of environmental conditions variable (Y2) in explaining the variations around the variables Breeding Place/Site (Y3) of 0.303. 
- Contributions or the proportion of health services variables (X1), the behavior (Y1), the condition of the environment (Y2), Breeding Place/Site (Y3) in explaining the variations around the larva density (Y4) variable of 0.571.

The results from all the value R-square showed that all values R-square greater than zero. This means that the model of this research is already meet the goodness of Fit is required. The results of the calculation of the value of $Q$ square from the table 3., obtained the following result:

$$
\mathrm{Q}^{2}=1-((1-0.204) \times(1-0.229) \times(1-0.303) \times(1-0.571))=0.877
$$

This can be interpreted that the model is able to explain the larva density (Y4) of $87.7 \%$, and the rest is explained by other variables outside the model. From the appropriate model, so it can be in interprets each path coefficient. The coefficient of the path coefficient is the hypothesis in this research that can be performed in the following structural equation:

$$
\begin{array}{ll}
\mathrm{Y} 1=0.066 \mathrm{X} 1 & , \mathrm{R}^{2}=0.204 \\
\mathrm{Y} 2=0.148 \mathrm{Y} 1+0.091 \mathrm{Y} 3 & , \mathrm{R}^{2}=0.229 \\
\mathrm{Y} 3=0.059 \mathrm{Y} 1 & , \mathrm{R}^{2}=0.303 \\
\mathrm{Y} 4=0.169 \mathrm{X} 1-0.205 \mathrm{Y} 1-0.324 \mathrm{Y} 2-0.054 \mathrm{Y3} 3 & , \mathrm{R}^{2}=0.571
\end{array}
$$

Structural Model tests (Inner Weight) demonstrated through the results of the structural path coefficient. The results of the structural path coefficient (Inner Weight) and the value of the full significance is shown in Table 5.

Table 5. Test the Inner Weight against the larva density rainy season with the Bootstrap

\begin{tabular}{lccc}
\hline The influence & Coefficient & \multicolumn{2}{c}{ (Bootstrap B=500) } \\
& Orginal & Coefficient & $\mid$ T-Statistics $\mid$ \\
\hline The Ministry of Health (X1) $\rightarrow$ behavior (Y1) & 0.066 & 0.073 & 1.988 \\
The behavior (Y1) $\rightarrow$ environment condition (Y2) & 0.148 & 0.147 & 5.257 \\
Breeding Place/Site (Y3) $\rightarrow$ environment condition (Y2) & 0.091 & 0.097 & 3.262 \\
The Ministry of Health (X1) $\rightarrow$ Larva density (Y4) & -0.169 & -0.170 & 5.714 \\
The behavior (Y1) $\rightarrow$ Larva density (Y4) & -0.205 & -0.212 & 6.676 \\
The condition of the environment (Y2) $\rightarrow$ Larva density (Y4) & -0.324 & -0.329 & 11.956 \\
Breeding Place/Site (Y3) $\rightarrow$ Larva density (Y4) & -0.054 & -0.056 & 1.993 \\
The behavior (Y1) $\rightarrow$ Breeding Place/Site (Y3) & 0.059 & 0.061 & 2.138 \\
\hline
\end{tabular}

On the test of the bootstrap samples $B=500$ give significant results, then continued in the analysis with chart form as follows: 


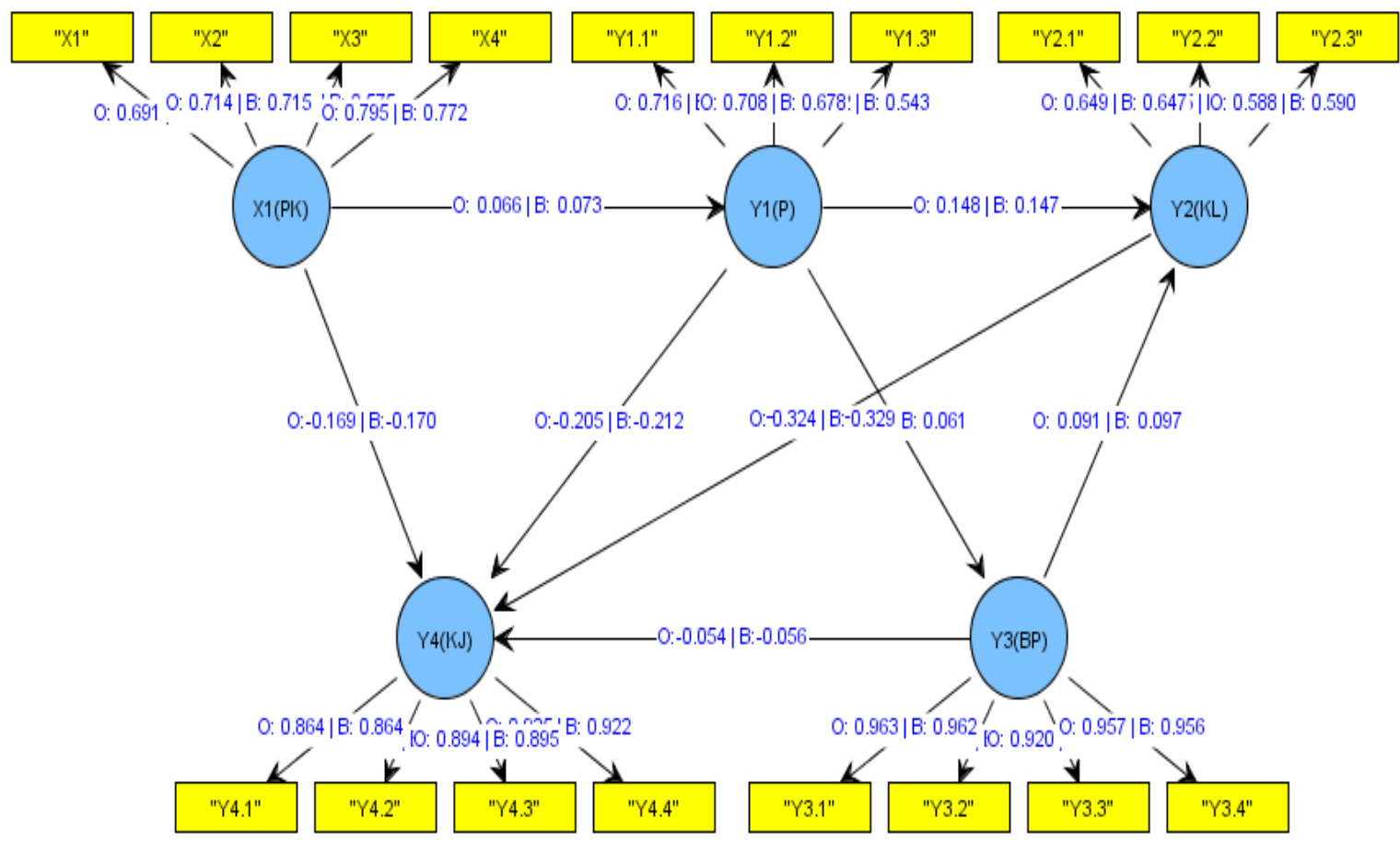

Figure 3. The Relationship of Ministry Health, Behavior, Environment Condition, Braiding Place against the Larva density on Rainy Season with estimates of the Bootstrap follows:

Based on the Table 5 and Figure 3, interpretation of each path coefficient is as

- The Ministry of Health (X) influential significant and positive toward the behavior (Y1). This can be seen from the path marked by the positive coefficient of 0.066 with $\mathrm{T}$-value of 1.988 Statistics greater than t-table $=1.96$. Thus the Health Services (X) directly impact on the behavior of (Y1) of 0.066 which means that every there is increasing Health Services (X) then will increase the behavior (Y1) of 0.066.

- The behavior (Y1) influential significant and positive impact on the condition of the environment (Y2). This can be seen from the path marked by the positive coefficient of 0.148 with T-value of 5.257 Statistics greater than t-table $=1.96$. Thus the behavior (Y1) directly impact on the condition of the environment (Y2) of 0.148 which means that every there is increasing the behavior (Y1) then will improve the condition of the environment (Y2) of 0.148.

- Breeding Place/Site (Y3) influential significant and positive impact on the condition of the environment (Y2). This can be seen from the path marked by the positive coefficient of 0.091 with T-value of 3.262 Statistics greater than t-table $=1.96$. Thus the Breeding Place/Site (Y3) directly impact on the condition of the environment (Y2) of 0.091 which means that every there is increasing Breeding Place/ Site (Y3) then will improve the condition of the environment (Y2) of 0.091.

- The Ministry of Health (X) significant and negative effect on the larvae density (Y4). This can be seen from the path marked by the negative coefficient of 0.169 with Tvalue of 5.714 Statistics greater than t-table $=1.96$. Thus the Health Services (X) directly impact on the larvae density (Y4) of -0.169 which means that every there is increasing Health Services (X) then will reduce the larvae density (Y4) of 0.169. 
- The behavior (Y1) significant and negative effect on the larvae density (Y4). This can be seen from the path marked by the negative coefficient of 0.205 with T-value of 6.676 Statistics greater than $\mathrm{t}$-table $=1.96$. Thus the behavior (Y1) directly impact on the larvae density (Y4) of -0.205 which means that every there is increasing the behavior (Y1) then will reduce the larvae density (Y4) of 0.205.

- The condition of the environment (Y2) significant and negative effect on the larvae density (Y4). This can be seen from the path marked by the negative coefficient of 0.324 with T-value of 11.956 Statistics greater than $\mathrm{t}$-table $=1.96$. Thus the condition of the environment (Y2) directly impact on the larvae density (Y4) of -0.324 which means that every there is increasing environmental conditions (Y2) then will reduce the larvae density (Y4) of 0.324 .

- Breeding Place/Site (Y3) significant and negative effect on the larvae density (Y4). This can be seen from the path marked by the negative coefficient of 0.054 with Tvalue of 1.993 Statistics greater than t-table $=1.96$. Thus the Breeding Place/Site (Y3) directly impact on the larvae density (Y4) of -0.054 which means that every there is increasing Breeding Place/Site (Y3) then will reduce the larvae density (Y4) of 0.054 .

- The behavior (Y1) influential significant and positive for the Breeding Place/Site (Y3). This can be seen from the path marked by the positive coefficient of 0.059 with the value of the $\mathrm{T}$ statistics of 2.138 greater than $\mathrm{t}$-table $=1.96$. Thus the behavior (Y1) directly impact on the Breeding Place/Site (Y3) of 0.059 which means that every there is increasing the behavior (Y1) then will increase the Breeding Place/Site (Y3) of 0.059 .

The relationship is not directly between the exogenous latent variables (health services (X)). with latent variable endogenous mediator/ intervening (behavior (Y1). the condition of the environment (Y2). Breeding Place/Site(Y3)) and endogenous latent variable (larvae density)). The Influence of indirect behavior (Y1) on health services (X) against larvae density (Y4) of -0.014. environment condition (Y2) on the behavior (Y1) to larvae density (Y4) of -0.048. and on breeding place/site (Y3) to larvae density (Y4) of -0.029. while the influence of indirect breeding place/site (Y3) on the behavior (Y1) to larvae density (Y4) of -0.003 .

\section{CONCLUSIONS}

The results of the study showed with SEM based variance approach that this research model meets the goodness of Fit is required. Larva density model is the best model based on the criteria of $\mathrm{R}^{2}$ and $\mathrm{Q}^{2}$, which is capable of described by the ministry of health, the behavior, the condition of the environment, breeding place/site of $87.7 \%$, and the rest is explained by other variables outside the model. The ministry of health, the behavior, the condition of the environment, and breeding place/site effect on the larva density. The ministry of health with the highest indicator counseling, latent variable behavior with the highest indicator knowledge, latent variable environmental conditions with the highest indicator water temperature, latent variable breeding Place/site with the highest indicator ingredients container, and latent variable larva density with the highest indicator breateau index. The ministry of health in explaining the variations around the variables behavior model of gaining 0.204 , behavior, breeding place/site in explaining the variation around environmental conditions variable of 0.229 , environment condition in explaining the variations around the variables breeding place/site of 0.303 , and health services, the behavior, the condition of the 
environment, breeding place/site in explaining the variations around the larva density variable of 0.571 . Environmental conditions the dominant factor in influencing the decline in the larva density of 32.4 percent.

\section{REFERENCES}

[1] Kementrian Kesehatan Republik Indonesia (Kemenkes RI). Profil Kesehatan Indonesia 2014. Jakarta, 2015.

[2] Kementrian Kesehatan Republik Indonesia (Kemenkes RI). Petunjuk Teknis Jumantik - DSN Anak sekolah. Jakarta, 2014.

[3] Dinas Kesehatan Kota Banjarbaru, Profil Kesehatan Kota Banjarbaru. Banjarmasin: Dinas Kesehatan Propinsi Kalimantan Selatan, 2015.

[4] Badan Penelitian dan Pengembangan Kesehatan RI, Riset Kesehatan Dasar tahun 2013, Kemenkes RI, Jakarta, 2014.

[5] Kementrian Kesehatan Republik Indonesia (Kemenkes RI). Buletin Jendela Epidemiologi. Jakarta, 2010.

[6] V. G. M. Prokovec, U. Kitron, B. Montgomery, P. Horne, and S. Ritchie, "Quatifying The Spatial Dimention of Dengue Virus Epedemic spead wiithin a Tropical Urban Environment", Plos Neglected Tropical Diseases, 4 (12). e920.doi:10.137, 2010.

[7] G. Anuraga dan B.W. Otok, "Pemodelan kemiskinan di Jawa Timur dengan Structural Equation Modeling-Partial Least Square", Statistika, volume 1, No2 2, Surabaya, 2013.

[8] T. A. Azomahou, M. Goeddhuys, P. N. Van, "A Structrural Nonparametric Reappraisal of the $\mathrm{CO}_{2}$ Emissions-Income Relationship", Documennts de Travail, Bureau d"economic Theorique at Applique (BETA), pp.1-6, 2010.

[9] K. A. Bollen, J. Pearl, "Eight Mythh About Causality and Structural Equation Models", In Morgan, ed. Handbook of Causal for Social Research. Chapel Hill and Los Angeles: Springer. pp.301-28, 2013.

[10] K. E. Fischer, "Decision Making in Healtcare: A Practical Application of Partial Least Square Path Modelling Coverage of Newborn Screening Program", BMC Medical Informatic \& Decision Making, pp.1-13, 2012.

[11] S. Y. Lee and Y. M. Xia, "Maximum Likelihood Methods In Treating Outliers and Symmtrically Heavy-Tailed Distributions For Nonlinear Structural Equation Models With Missing Data", Psychometrika, 71 no. 3 DOI: 10.1007/s113360061264-1, pp.565-85, 2006.

[12] K. E. Schermelleh, C. Werner, H. Moosbrugger, "Nonlinear Structural Equation Modeling: Is Partial Least Squares an Alternative?", In Meeting of The Working Group Structural Equation Modeling. Berlin, Germany, 2009.

[13] WHO, Comprehensive guidelines for prevention and Control of Dengue and Dengue Haemorragic fever. revised and expanded edition ed. New Delhi: WHO Library Cataloging in Publication Data, 2006.

[14] S. Notoatmodjo, Promosi Kesehatan, Teori dan Aplikasi, Jakarta, PT. Rineka Cipta, halaman 43-64, 2010. 
[15] W.W. Chin, The Partial Least Squares Approach for Structural Equation Modeling. Cleveland. Ohio, 1998.

[16] Kemenkes RI, “Demam Berdarah Dengue di Indonesia tahun 1968-2009”, Buletin Jendela Epidemiologi, Volume 2, tahun 2010, halaman 1-14, 2010.

[17] Fathurrahman, Perbedaan Bahan Ovitrap Perangkap Telur Nyamuk terhadap Keberadaan Telur Nyamuk Aedes, sp, Skripsi Politeknik Kesehatan, Banjarmasin, 2017.

[18] U. F. Achmadi, Dasar-Dasar Penyakit Berbasis Lingkungan. 1st ed. Jakarta: P.T. Rajagrafindo Persada, 2011.

[19] Anies, Manajemen Berbasis Lingkungan, Solusi Mencegah dan Menanggulangi penyakit Menular, PT Elex Media Komputindo, Jakarta, 2006.

[20] M. C. Anthony, D. B. C. Alistair, G. G. H. Amul, A. Sharma, "Health Governance and Dengue in Southeast Asia", NTS Report No 2, Singapore, 2015.

[21] L. C. Chan, Singapore Dengue Haemorragic Fever Control Programme A Case Study On The Succesfull, Control of Aedes Aegypty and Aedes albopictus Using Mainly Environmental Measures As A Part of Integrated Vector Control, Seamic, Tokyo, 1985. 